IZA DP No. 6705

Stand Your Ground Laws and Homicides

Chandler McClellan

Erdal Tekin

July 2012 


\title{
Stand Your Ground Laws and Homicides
}

\author{
Chandler McClellan
}

Georgia State University

\section{Erdal Tekin}

Georgia State University, NBER and IZA

\section{Discussion Paper No. 6705 \\ July 2012}

IZA

P.O. Box 7240

53072 Bonn

Germany

Phone: +49-228-3894-0

Fax: +49-228-3894-180

E-mail: iza@iza.org

Any opinions expressed here are those of the author(s) and not those of IZA. Research published in this series may include views on policy, but the institute itself takes no institutional policy positions.

The Institute for the Study of Labor (IZA) in Bonn is a local and virtual international research center and a place of communication between science, politics and business. IZA is an independent nonprofit organization supported by Deutsche Post Foundation. The center is associated with the University of Bonn and offers a stimulating research environment through its international network, workshops and conferences, data service, project support, research visits and doctoral program. IZA engages in (i) original and internationally competitive research in all fields of labor economics, (ii) development of policy concepts, and (iii) dissemination of research results and concepts to the interested public.

IZA Discussion Papers often represent preliminary work and are circulated to encourage discussion. Citation of such a paper should account for its provisional character. A revised version may be available directly from the author. 


\section{ABSTRACT}

\section{Stand Your Ground Laws and Homicides*}

The controversies surrounding Stand Your Ground laws have recently captured the nation's attention. Since 2005, eighteen states have passed laws extending the right to self-defense with no duty to retreat to any place a person has a legal right to be, and several additional states are debating the adoption of similar legislation. Despite the implications that these laws may have for public safety, there has been little empirical investigation of their impact on crime and victimization. In this paper, we use monthly data from the U.S. Vital Statistics to examine how Stand Your Ground laws affect homicides. We identify the impact of these laws by exploiting variation in the implementation of these laws across states. Our results indicate that Stand Your Ground laws are associated with a significant increase in the number of homicides among whites, especially white males. According to our estimates, between 4.4 and 7.4 additional white males are killed each month as a result of these laws. We find no evidence to suggest that these laws increase homicides among blacks. Our results are robust to a number of specifications and unlikely to be driven entirely by the killings of assailants. Taken together, our findings raise serious doubts against the argument that Stand Your Ground laws make America safer.

JEL Classification: $\quad 11, \mathrm{~K} 14, \mathrm{~K} 42$

Keywords: $\quad$ homicide, stand your ground, castle doctrine, guns, crime

Corresponding author:

Erdal Tekin

Department of Economics

Andrew Young School of Policy Studies

Georgia State University

P.O. Box 3992

Atlanta, GA 30302-3992

USA

E-mail: tekin@gsu.edu

\footnotetext{
${ }^{*}$ We would like to thank Chris Herbst and Mark Hoekstra for their comments and suggestions.
} 


\section{Introduction}

On February 26, 2012, the 17 year old teenager Trayvon Martin was fatally shot by George Zimmerman, a community watch coordinator for a gated community in Sanford, Florida. ${ }^{1}$ Based on preliminary physical evidence and the testimony provided by Zimmerman that he had acted in self-defense, the Sanford Police Department did not pursue criminal prosecution against Zimmerman, at least initially, under the Florida's statute on justifiable use of force. ${ }^{2}$ The circumstances that triggered the shooting and the initial decision not to charge Zimmerman have prompted tremendous media coverage and public attention and moved a wave of self-defense statutes recently introduced by states to the forefront of jurisprudence and policy debates. These new statutes, which are also known as Stand Your Ground (SYG) laws, allow individuals to use force, including lethal force, in self-defense when there is reasonable belief of a threat, without having any duty to retreat first.

Historically, the right to defend one's home against intruders without a duty to retreat is well-protected by the principle of "Castle Doctrine". Rooted in the notion that "a man's home is his castle", this principle, recognized by common law, held an exception to the duty to retreat when an individual faced an attack in his home. ${ }^{3}$ The key difference in this new wave of laws is that they extend the Castle Doctrine to apply to

\footnotetext{
${ }^{1}$ Although many of the facts surrounding the case are still unknown to the public, at the time of his death Trayvon did not have a weapon, but instead he was carrying a bag of candy and an iced tea back home. George Zimmerman was eventually arrested and charged with second-degree murder and is currently awaiting trial.

${ }^{2}$ According to Statute 776.013, which took effect on October 1, 2005, “(3) A person who is not engaged in an unlawful activity and who is attacked in any other place where he or she has a right to be has no duty to retreat and has the right to stand his or her ground and meet force with force, including deadly force if he or she reasonably believes it is necessary to do so to prevent death or great bodily harm to himself or herself or another or to prevent the commission of a forcible felony." See

http://www.leg.state.fl.us/statutes/index.cfm?App_mode=Display_Statute\&Search_String $=\& U R L=0700$ 0799/0776/Sections/0776.013.html.

${ }^{3}$ See Levin (2010) and Catalfamo (2007) for a summary of the historical origins of the Castle Doctrine.
} 
places outside the home, such as a vehicle, workplace, or anywhere else an individual has a legal right to be, and thus diminish or eliminate the long-standing duty to retreat. Since Florida introduced its SYG law in 2005, another seventeen states have passed some version of a SYG law that contains language granting immunity from criminal prosecution to individuals using defensive or deadly force to venues beyond homes. ${ }^{4}$

With a strong backing by the National Rifle Association (NRA), proponents of the SYG laws argue that they would have a deterrent effect on crime. They also contend that law-abiding citizens must be able to protect themselves from intruders and attackers without having to worry about criminal or civil penalties before taking action in selfdefense. Reflected in this argument is a diminished sense of confidence in the criminal justice system's ability to protect victims and the perceived discrepancy in the judicial system that emphasizes the due process rights of defendants over the rights of victims (Jansen and Nugent-Borakove, 2007). ${ }^{5}$ It has also been suggested that increased concerns about public safety in the aftermath of the terrorist attacks in 2001 and Hurricane Katrina in 2005 have played a role in the spread of SYG laws (Jansen and Nugent-Borakove, 2007).

Opponents, on the other hand, claim that these laws give too much freedom to private citizens to use deadly force, making them a license to kill rather than a protective measure (Megale, 2010; Kleindienst, 2005). It has been argued that these laws are open to abuses by those engaged in illegal activities or those with criminal records and may

\footnotetext{
${ }^{4}$ These states include Alabama, Arizona, Florida, Georgia, Indiana, Kansas, Kentucky, Louisiana, Michigan, Mississippi, Montana, New Hampshire, Oklahoma, South Carolina, South Dakota, Tennessee, Texas, and West Virginia. See Table 1 for more information.

${ }^{5}$ Following the passage of Florida's law, the Institute for Legislative Action (ILA) - the lobbying arm of the NRA - wrote "Without doubt, Florida's recently enacted "Castle Doctrine" law is good law, casting a common-sense light onto the debate over the right of self-defense. It reverses the pendulum that for too long has swung in the direction of protecting the rights of criminals over the rights of their victims." (NRAILA, 2006).
} 
lead to an increased number of people carrying guns and willing to use them (Formby, 2006; Weaver, 2008; Jansen and Nugent-Borakove, 2007). Along similar lines, it has been suggested that these laws could embolden individuals to stand their ground rather than simply walk away and could lead to individuals resorting to use of deadly weapons even during situations posing no imminent danger (Weaver, 2008; Florida Stand Your Ground Task Force, 2012). Another concern raised by critics over the expansion of the no duty to retreat to public areas is the amplified risk to innocent bystanders and public safety personnel and the possibility of increased violence due to retaliation (Jansen and Nugent-Borakove, 2007; Rios, 2012).

In the wake of recent attention received by SYG laws, a number of state legislatures have reacted by introducing bills to limit the application of these laws, while others are keeping alive bills to pass similar laws. Therefore, there is a real and immediate need to provide credible evidence on the overall impact of these laws on public safety in order to better inform the public during the current and upcoming legislative debates. Our analysis constitutes a significant attempt towards this goal.

Another motivating factor for the need for such analysis is a rise in the number of justified homicides nationally since 2005 (Federal Bureau of Investigation, 2010). According to data from the Uniform Crime Reports, the total number of justifiable homicides has steadily increased from 196 in 2005 to 278 in $2010 .^{6}$ This is in contrast to the total number of overall killings, which has continued to decline during the same period. However, it is not straightforward how to interpret the rise in justifiable homicides. On the one hand, it might be that more civilians are killing each other and

\footnotetext{
${ }^{6}$ The corresponding figures are 238 for 2006,257 for 2007,265 for 2008 , and 266 for 2009 . It is notable that this upward trend is solely due to an increase in the homicides committed with firearms and not accounted for by other dangerous weapons and knives or cutting instruments.
} 
claiming self-defense (Palazzolo and Barry, 2012). In other words, the increase in justifiable homicide might reflect deaths that would not have occurred otherwise. This might support the concerns raised by the critics over the SYG laws. On the other hand, it might also be a mechanical shift as the new laws now result in more deaths being labeled as justifiable homicides. Unfortunately, the official data sources like the Supplemental Homicide Reports do not allow detailed information on the nature of circumstance in each incident. Nevertheless, the coincidence in trend for justifiable homicides and the expansion of the new SYG laws is suggestive of a possible causal link, which deserves closer investigation.

In this paper, we examine the impact of the recently introduced SYG laws on homicides due to firearm assaults using data from the U.S. Vital Statistics. In order to identify the causal impact of these laws, we employ a difference-in-difference methodology by exploiting the variation across states over time in the effective date of these laws. It is important to note that our focus is on states that have passed SYG laws with an explicit language extending the right to self-defense with no duty to retreat to any place where a person has a legal right to be. ${ }^{7}$ Since the majority of these new laws were passed in a window of a three year period between 2005 and 2007, it is difficult to leverage variation with annual data to apply the difference-in-difference method. In order to avoid this problem, we use data from Vital Statistics, which provides the universe of

\footnotetext{
${ }^{7}$ There have been a few states that passed versions of SYG laws that did not extend the no duty to retreat principle to apply to public places. These are not included in our treatment states. In our opinion, it is the provision of "no duty to retreat at any place a person has a legal right to be" that is the controversial aspect of these laws and also the one that has received much of the attention recently. In fact, the other provisions like no duty to retreat at home, also known as the Castle Doctrine, have been part of the common law for decades almost everywhere and individuals have rarely been prosecuted for using deadly force in selfdefense in their homes. Nevertheless, we conducted a robustness analysis to determine whether any of our results are confounded by the impact of these other provisions. As discussed later in the paper, our results are not influenced by these other provisions.
} 
deaths in the U.S. at the monthly level. We find that the SYG laws increase firearm related homicides among whites, especially white males. Our results indicate that between 4.4 and 7.4 additional white males are killed each month as a result of these laws. We find no evidence to indicate that these laws cause an increase in homicides among blacks. Our results are robust to a number of specifications and unlikely to be driven entirely by the killings of assailants. These findings raise serious doubts about the claim that SYG laws make America safer.

The remainder of the paper is organized as follows. Section II provides background information on the publicity generated by SYG laws and reviews the existing evidence on the impact of these laws. Section III discusses the data used in the analysis. Section IV describes our empirical approach. Section V presents our main results, and Section VI offers a set of conclusions.

\section{Background}

Despite the tremendous publicity generated by the SYG laws and the significant ramifications that these laws may have on public health and safety, to date there has been little investigation of the potential impact of these laws on outcomes, such as crime rates and victimization. Most of what is currently known on the potential consequences of these laws are descriptive and come from media reports. For example, according to the Tampa Bay Times, "justifiable homicides" in Florida steadily increased from an annual average of 34 during the first half of the 2000s to 105 in 2009 (Montgomery and Jenkins, 2010). ${ }^{8}$ Furthermore, an independent review panel, which examined Florida's SYG law, cites documentation of the law's application to excuse killings in neighborhoods, bar

\footnotetext{
${ }^{8}$ The figures stood at 31, 43, 33, 102, 93, and 105 in years from 2004 to 2009, respectively.
} 
brawls, gang shootouts, and road-rage incidents (Florida Stand Your Ground Task Force, 2012). In a comprehensive effort, the Tampa Bay Times has identified about 200 SYG cases and their outcomes through media reports, court records and interviews with prosecutors and defense attorneys in Florida (Hundley et al., 2012). The report finds that in about 70 percent of the cases where the SYG law was invoked to avoid prosecution, individuals have gone free. The report also cites numerous examples which support the perception that these laws encourage individuals to be aggressive even in situations where retreat is possible. ${ }^{9}$

Despite these concerns, there are also others who argue that the colorful examples highlighted in the media draw a misleading picture of the actual impact of these laws and that the laws have largely been successful in protecting citizens against wrongful attacks and intrusions. There have also been examples cited in support of the desirable impact of these laws. For example, a woman with a known history of prostitution killed a client with his own gun when he had threatened to kill her. The murder charge against the woman, who could have been prosecuted under the old law, was dropped because of Florida's newly enacted SYG law (Lake, 2006).

While there is an abundance of anecdotal evidence on the impact of SYG laws on crime, there is very little credible investigation of the subject to determine whether these laws represent good policy for public safety. ${ }^{10}$ One exception is a recent working paper

\footnotetext{
${ }^{9}$ For example, the report states that "During an argument at a 2009 party in Fort Myers, Omar Bonilla fired his gun into the ground and beat Demarro Battle, then went inside and gave the gun to a friend. If Battle feared for his life, he had time to flee. Instead, he got a gun from his car and returned to shoot Bonilla three times, including once in the back. Battle was not charged in the slaying."

${ }^{10}$ Although there has been little empirical investigation of the SYG laws, there is a wealth of research examining the effects of prevalence of gun ownership and gun laws on crime and victimization. The findings from this research are mixed. On the one hand, a large number of studies find evidence to support that gun prevalence to increase crime and victimization (Cook and Ludwig, 2003, 2006; Duggan, 2001; Mocan and Tekin, 2006; Wells and Horney, 2002; MacDonald and Parker, 2001). On the other hand, there
} 
by Cheng and Hoekstra (2012), which examines the impact of the recent wave of selfdefense laws on crime and homicides using data from the FBI Uniform Crime Reports (UCR). The study finds no evidence that these laws have any deterrence effect on crimes such as burglary, robbery, and aggravated assault, but increase murder. While Cheng and Hoekstra (2012) is a useful attempt to shed light into the impact of self-defense laws on crime and victimization, our study has a number of important differences. First, we focus on the impact of SYG laws that extended the right to self-defense with no-duty to retreat in venues outside homes, while the primary focus of Cheng and Hoekstra (2012) is the self-defense laws with a broader scope. Second, we examine the impact of the SYG laws separately by gender and race. On the one hand, there is evidence to suggest that the application of these laws may have a disproportionally larger impact on minorities (Hundley et al, 2012; Jansen and Nugent-Borakove, 2007). On the other hand, proportion of whites owning guns is substantially larger than that of blacks, suggesting that the laws may also have a larger impact on whites (Project America, 2008). As it turns out, race and gender specific heterogeneity in the impact of SYG laws is in fact important and ignoring it would produce an incomplete picture of the consequences of the SYG laws. Second, we use data on firearm related homicides from the U.S. Vital Statistics, while Cheng and Hoekstra (2012) use data from the UCR. The discrepancies in homicides between the UCR and the Vital Statistics are well-documented (Harris et al., 2002; Loftin et al., 2008; Wiersema et al. 2000; Decker and Pyrooz, 2010). For example, Loftin et al. (2008) find large differences between the UCR data and Vital Statistics data, with substantial undercount in the UCR estimates of the number of homicides. Note that

are also a number of studies documenting that gun ownership and less restrictive regulations lead to less crime and victimization through deterrence (Lott and Mustard, 1997; Lott, 2000; Lott and Whitley, 2001; and Mustard, 2001). 
undercounting may particularly be an important issue if the extent of it differs between states with SYG laws and those that do not have these laws. Vital Statistics is usually considered the gold standard of U.S. mortality measurement (Harris et al., 2002). Third, we focus on monthly homicides while Cheng and Hoekstra (2012) use annual data in their analysis. It is understandable that Cheng and Hoekstra (2012) conduct their analyses with annual data since the monthly data from the UCR records are particularly problematic. For example, incomplete reporting is a major problem with the UCR at the monthly level. A large fraction of jurisdictions does not reliably provide data on a monthly basis, but rather most jurisdictions provide aggregates in one particular month, typically December. The records of justifiable killings provided by the UCR may also be problematic. Kleck (1988) discusses a number of reasons why the FBI's total counts of justifiable homicides represent only a minority of all civilian defensive homicides. For example, there are examples of cases labeled by police as justifiable homicides, but they are not reported as such to the FBI because of the unwillingness by the police to spend much time recording homicides where the prosecution of the murderer was not expected to be pursued. ${ }^{11}$

An analysis with annual data is not the most ideal in this case because, with the exception of three states, all Castle Doctrine laws were passed in a period of three years between 2006 and 2008. In particular, 12 states passed these laws in 2006 and two states passed them in 2007. The number of states that passed a SYG state in 2005 and 2008 is only one. Clustering of laws around such a narrow time window would reduce variation

\footnotetext{
${ }^{11}$ Another limitation of the UCR data is that federal law enforcement agencies in certain jurisdictions do not participate in the UCR program. Thus, homicides occurring in places like prisons, national parks and Indian reservations, which are not reported by state or local law enforcement agencies, will not show up in the UCR system (Rokaw et al., 1990), but will appear in the Vital Statistics.
} 
over time in the spread of these laws, which can be important for identification in a difference-in-difference framework. Given the monthly frequency of our data, we are able to utilize variation in homicides within a twelve month period. This also helps us capture seasonality in the homicides.

\section{Data}

Our main data source is firearm related homicide victimization between 2000 and 2009 drawn from the U.S. Vital Statistics. These data are made available from the National Center for Health Statistics (NCHS) through a contractual agreement. The Vital Statistics records each instance of death based on information from death certificates filed with the vital statistics offices of each state and the District of Columbia. Each record contains pertinent demographic information as well as the locality, date, and cause of death. The cause of death is then recoded by the NCHS based on the Tenth Revision of the International Classification of Disease (ICD-10). For our purposes, we focus on firearm related homicides committed by private citizens. ${ }^{12}$ The individual records are aggregated to the state and month in which they occur. In order to construct homicide rates, we obtained population data from the U.S. Census' Intercensus County Population Estimates for each state and each year.

Our main explanatory variable is SYG defined as a binary variable that takes on the value of 1 if a state has a SYG law in effect in a particular month of the year and 0 otherwise. The month the SYG law has become effective is determined by information

\footnotetext{
${ }^{12}$ We exclude justified shootings by police or other law enforcement officers and suicides by firearms from our analysis.
} 
provided by the state legislature of each state in which a SYG law has been enacted. ${ }^{13}$ In the month the law became effective, we coded the SYG as the proportion of days within the particular month in which the law was in effect as the treatment variable. ${ }^{14}$ The first state to pass a SYG law that has extended the right to self-defense with no-duty to retreat in venues outside homes is Florida. By the end of 2009, a total of 18 states had similar laws in their criminal code. Figure 1 displays the rapid increase in the spread of these laws during the second half of the 2000s. ${ }^{15}$ A complete list of these states and the exact dates that their SYG laws have become effective are listed in Table $1 .{ }^{16}$ Note that a number of states have expanded their Castle Doctrine laws without extending no duty to retreat to public places. ${ }^{17}$ These states are listed in column 3 of Table 1 . In our interpretation, the expansion of no duty to retreat in public venues is the most dramatic aspect of these laws with the most significant ramifications. However, we also recognize that these other provisions may confound our findings if they have significant impacts on homicides. In the results section, we present evidence from a robustness analysis to

\footnotetext{
${ }^{13}$ For some states, the effective date is the day the legislation is signed into law by the governor, while for others, it is stipulated in the text of the legislation or set as a specific day of the year on which all passed laws become effective.

${ }^{14}$ We tested the robustness of our results to alternative ways of constructing the treatment variable. For example, we coded SYG as 1 and then 0 in the month it became effective and our results remained the same in each case.

${ }^{15}$ Utah had a law that allowed the right of self-defense outside the home since 1994.

${ }^{16}$ We interpret Indiana's SYG law as one that removes duty to retreat in any place someone has a legal right to be. Note that this differs from the interpretation in Cheng and Hoekstra (2012). Indiana's law states that "if the person reasonably believes that force is necessary to prevent serious bodily injury to the person or a third person or the commission of a forcible felony. No person in this state shall be placed in legal jeopardy of any kind whatsoever for protecting the person or a third person by reasonable means necessary." (see http://www.in.gov/legislative/bills/2006/PDF/HE/HE1028.1.pdf). There are no limits as to where the forcible felony should occur and presumably can be construed to mean anywhere. Given the uncertainty about the language in Indiana's law, we estimated our models after recodifying Indiana as a non-SYG state. Our results remained very similar. These results are available from the authors upon request.

${ }^{17}$ These expansions typically curtail civil liabilities for justified killings or establish a presumption of reasonableness.
} 
indicate that our results are not influenced by the presence of these other provisions and in fact it is the stand your ground provision that is driving our findings.

We control several characteristics of states in our analysis. These include the racial composition of state (i.e., percentage black, white, and Hispanic), the age distribution of state population (i.e., percentage aged 15-19, 20-24, 25-34), and the proportion of state population living in urban areas. Data on age distribution of state population, racial and ethnic composition, and urbanization are obtained from the Bureau of the Census. Next, we supplement our models with data on the number of law enforcement agencies and the number of state prisoners obtained from the annual Justice Expenditure and Employment Abstract of the Bureau of Justice statistics. Finally, we control for the state's unemployment rate, the poverty rate, and the political party that controls the governorship in the state. These measures are compiled from the University of Kentucky's Center for Poverty Research.

Table 2 provides the means and standard deviations for our control variables. We present these summary statistics for the full sample and for the subsets of non-SYG and SYG states. The average monthly homicide counts are 18.81 in non-SYG states and 24.55 in SYG states. The homicide rate is also higher among SYG states with 0.19 deaths per month per 100,000 residents deaths compared to non-SYG states, which have an average homicide rate of 0.16 per month per 100,000 residents. Of the 6,120 statemonth-year observations, 674 (11 percent) are zeros due to no homicides committed during those months. The largest homicide count is observed in California, a non-SYG state, with 198 deaths in September 2002. The largest number of homicides among our SYG states was observed in Texas in May 2009 with 106 homicides. If we consider 
homicide rates per population rather than homicide counts, then the largest homicide rate was observed in District of Columbia, again a non-SYG state, in July 2002 with 2.27 homicides per 100,000 residents. Among the SYG states, the largest homicide rate was in Louisiana in July 2009 with 0.66 homicides per 100,000 residents. Table 2 also shows that SYG and non-SYG states differ in several observable characteristics. In particular, SYG states have a higher percentage of black population, more likely to have a Republican governor, higher incarceration rates and more police officers. These states also tend to be more urban, and have a higher poverty rate.

\section{Empirical Strategy}

We are interested in examining the impact of SYG laws on homicides due to gun assaults. The key empirical challenge in answering this question stems from the fact there may be a myriad of other factors that might be correlated with the passage of these laws and independently affect homicides due to gun assaults. Therefore, a simple before-andafter approach would fail to identify the effect of SYG laws unless the spread of these laws across states was effectively random with respect to both observable and unobservable characteristics of those states. However, this assumption is unlikely. For example, if the law enforcement officers anticipate that these laws may lead to an increase in gun prevalence and escalation of violent conflicts, then they may react by intensifying their policing efforts. Alternatively, if the new laws result in an increase in the number of regular citizens taking up arms to serve as community watch volunteers, then the law enforcement officers may actually reduce their patrolling activities in some neighborhoods. Furthermore, the states that pass the SYG laws are different than other 
states in many ways. For example, in a study examining the evolution of these laws, Boots et al. (2009) show Republicans are more likely to initiate and sign SYG bills into law than Democrats. With respect to the geographic representation, as shown in Table 1, southern states are more likely to have a SYG law. These also tend to be the states with widespread support for gun rights and a strong presence of pro-gun organizations like the NRA. If cultural or socio-economic differences across states are correlated with both the passage of these laws and homicides, then failing to control for them would lead to a bias in the estimated impact of SYG laws on homicides.

Moreover, the spread of SYG laws coincides with a period of increased legislative activity towards loosening gun laws. For example, in June 2008, the U.S. Supreme Court, in District of Columbia v. Heller, struck down the District of Columbia's ban on handguns and reinforced an individual's right to possess firearms as a fundamental right confirmed by the U.S. Constitution. This example highlights the importance of properly accounting for other national developments in order to obtain an unbiased estimate of the law's impact.

To address these problems, we employ a difference-in-difference strategy, exploiting the variation in the timing of these laws across states. Our key identification assumption is that, in the absence of the SYG laws, homicide rates would have trended similarly between states which had enacted these laws and those which had not. One potential threat to our identification strategy is that the decision to pass a SYG law may reflect policy endogeneity. While pro-gun activists have intensified their campaigns both at the legislative and grassroots levels in the last decade, it is not exactly clear what specifically prompted these particular states to extend the Castle Doctrine in such a 
controversial way. As Jansen and Nugent-Borakove (2007) point out, there are many unanswered questions about the impact of these Castle Doctrine expansion policies, particularly because there is no evidence to determine why these specific expansions were proposed in the first place. ${ }^{18}$ One thing that is clear is that these laws could not have been introduced as a reaction to a wave of crime epidemic in the states that have passed these laws. If anything, crime rates have been on the decline virtually everywhere in the U.S. during this period. Furthermore, as illustrated in Figure 2, trends in homicide rates are fairly similar across states that passed SYG laws and those that did not prior to passage of these laws. The line with solid circles reflects the smoothed average homicide rate in a given month and a year among the treatment states, i.e., the states that passed a SYG law since 2005. The vertical line presents the month and the year in which the SYG law became effective in each of the treatment states. Since these laws became effective at different times, the graph is centered in the month and year the SYG law became effective in each of the SYG states (time 0) and tracks homicide rates in the months leading up to and after this period for 18 months (e.g., time 0 is 10/2005 for Florida and 6/2006 for Georgia). The line with solid diamonds in Figure 2 displays the smoothed average homicide rate across states that fall into the control group, i.e., those states that did not pass a SYG law. ${ }^{19}$

\footnotetext{
${ }^{18}$ Some suggest that increased concerns about public safety in the aftermath of the terrorist attacks in 2001 and Hurricane Katrina in 2005 have played a role in the spread of SYG laws (Jansen and Nugent-Borakove, 2007).

${ }^{19}$ To illustrate, assume we have three states with the SYG laws, which became effective on 10/2005, $6 / 2006$, and 12/2007, and three control states (X, Y, and Z) that did not pass a SYG law during the analysis period. Then the average homicide rate among the control states in time 0 is based on the homicide rates in states X, Y, and Z in 10/2005, 6/2006, and 12/2007. Similarly, the homicide rates in control states in time 1 is constructed as the average of homicide rates in states $\mathrm{X}, \mathrm{Y}$, and $\mathrm{Z}$ in 11/2005, 7/2006, and 1/2008. The average homicide rates for the months prior to time 0 are constructed in a similar fashion.
} 
As shown in Figure 2, the homicide rates are higher in treatment states than the control states prior to the effective dates of SYG laws. Note that the differences in levels of homicide between the two types of states are not a concern for our identification because we condition on state and month*year fixed effects. However, the SYG and nonSYG states follow a fairly similar homicide rate trend prior to the SYG laws, suggesting little evidence of systematic differences between the two groups of states other than differences in levels. Note that when we focus on combinations of gender and race, the picture becomes more blurred, especially for the homicides among the treatment states, because of volatility in the monthly rates of homicides. Nevertheless, the trends in homicide rates are similar for the large part prior to the SYG laws for both types of states. ${ }^{20}$ Following the enactment of SYG laws, the homicide rates start trending upwards in the treatment states, especially for white males and white females. Control states on the other hand exhibit no such trend. In fact, if anything the homicide rate trends downward for all gender and race groups. This is illustrative evidence that in the absence of SYG laws, the treatment states might have followed a similarly flat or downward trend. The difference-in-difference method can be formalized in a regression framework as follows:

$$
\mathrm{H}_{\mathrm{smy}}=\alpha \mathrm{SYG}_{\mathrm{smy}}+\mathbf{X}_{\mathrm{smy}} \beta+\mu_{\mathrm{s}}+\lambda_{\mathrm{my}}+\varepsilon_{\mathrm{smy}}
$$

where $\mathrm{H}_{\mathrm{smy}}$ is the rate of homicides in state $s$ in month $m$ in calendar year $y$. $\mathrm{SYG}_{\mathrm{smy}}$ is our key explanatory variable, which equals one if state $s$ has a SYG law effective in

\footnotetext{
${ }^{20}$ Note that the volatility in homicides in SYG states is particularly higher because the number of states with a SYG law in effect decreases as one moves away from time 0 . In other words, the homicide rate is averaged over a decreasing number of states as one deviate from time 0 .
} 
month $m$ in calendar year $y$, and 0 otherwise. The $\mathbf{X}_{\text {smy }}$ is a vector of exogenous determinants of crime described above. The $\mu_{\mathrm{s}}$ are state fixed effects and would capture any time invariant, state specific factors, which may influence homicides. The $\lambda_{\text {my }}$ are month*year fixed effects that would account any seasonality-related trends as well as national changes in homicides that are common to all states. The $\varepsilon_{\text {smy }}$ is the usual error term. Note that our unit of observation is by state, year, and month. The coefficient of interest is $\alpha$, the impact of SYG laws on homicides. The standard errors are clustered at the state level to account for serial correlation (Bertrand et al., 2004).

Although the evidence illustrated in Figure 2 suggests that there is little evidence of policy endogeneity or systematic pre-existing trends that differ between the treatment and control states, we extend our baseline specification in equation (1) by including statespecific linear trends in addition to state and month*year fixed effects. These additional controls would account for any unobserved factors that trend over time within a state and are correlated with homicides. $^{21}$

We start empirical analysis with OLS models estimated in the logarithm of homicide rates per 100,000 state residents. ${ }^{22}$ However, estimating a proportional effects model is not straightforward in our case because of zero homicides observed in some states in certain months. To overcome this complication, we replaced zeros with ones, and estimated log-linear models with the resulting data. ${ }^{23}$ Next, we present results from

\footnotetext{
${ }^{21}$ We also experiment with specifications that control for state-specific quadratic trends as well as region*year fixed effects. These results did not cause any appreciable changes to the results presented here. ${ }^{22}$ The regressions are weighted by state population for the relevant demographic group. Our results are similar when we estimate these models using rates of homicide instead. These results are presented in Appendix Table 1.

${ }^{23}$ Our results do not change when we only use the non-zero observations. These results are available from the authors upon request.
} 
fixed-effects Poisson models. ${ }^{24}$ These models are particularly well-suited for our purpose given the count nature of our data and the fact that homicides are rare events, especially at the monthly level and in some smaller states. ${ }^{25}$ We use logarithm of monthly homicide counts and control for the logarithm of state population for the relevant race and gender group. ${ }^{26}$

\section{Results}

Table 3 presents OLS estimates of the impact of the SYG laws on logarithm of the homicides per 100,000 residents. Each cell in the table presents the coefficient on the indicator for SYG law and its standard error (adjusted for clustering at the state level). We present results for the full sample in Panel A, and then separately by race and by combinations of race and gender in Panels B through G. In each panel, column (1) shows the SYG estimates from a specification expressed in equation (1) that controls for state, month, and year fixed effects; column (2) displays the estimates from the specification that adds state specific annual time trends.

\footnotetext{
${ }^{24}$ One advantage of Poisson models is that, observed homicide rates of zero present no problem since Poisson regression does not require taking the logarithm of the dependent variable. However, one limitation of these models is the assumption that variance equals the mean. We use the robust option to obtain robust standard errors as recommended by Cameron and Trivedi (2010), which should mitigate concerns over the equivariance assumption. The violation of the equivariance assumption still produces consistent estimates but standard errors could be biased towards zero. Using Poisson regression also allows us to cluster standard errors at the state level.

${ }^{25}$ In addition to fixed effects Poisson models, we estimated fixed effects Negative Binomial models to account for potential overdispersion in the data. The Negative Binomial results are not appreciably different from the Poisson or OLS results presented here and are available from the authors upon request.

${ }^{26}$ By adding the logarithm of state population, Poisson regression becomes an analysis of rates of homicides per population, rather than an analysis of counts of homicides (Osgood, 2000). In this specification, fixing the coefficient on the $\log ($ population) to be unity would assume that per capita homicide rates are constant across states with different population sizes, controlling for the other explanatory variables. However, we do not impose this assumption on our data by estimating a coefficient on $\log$ (population) (Osgood, 2000; Bedard and French, 2009).
} 
As shown in Panel A of Table 3, the estimates are positive and significant in both specifications, suggesting that SYG laws increase the rate of homicides. The estimate in the second row indicates that having a SYG law is associated with a 7.1 percent increase in the homicide rate. When we consider the impact of SYG laws on homicides separately by race, an interesting picture emerges, suggesting that the positive impact of these laws only applies to whites, while the estimates for blacks are negative but not statistically significant. The point estimate on the specification in column (2) indicates that the SYG law increases firearm related homicide rate among whites by 12.2 percent. Given that the SYG states had an average of 0.234 white homicides per 100,000 persons in the month prior to SYG law, the estimate implies that these laws result in about 0.03 additional white individuals per 100,000 getting killed in each state each month. With a white population of 28.4 million in the SYG states, this is equal to an additional 8.09 deaths per month.

Next, we turn our attention to the SYG estimates separately by race and gender. These results, presented in Panels D through G of Table 3, reveal that the positive effect of SYG laws among whites is primarily driven by homicides of white males, while the impact among white females is no longer significant when we control for state specific trends. With an average homicide rate of 0.354 per 100,000 for white males in the month prior to the SYG laws, the SYG estimate of 0.156 translates into an approximately 0.055 additional homicides per 100,000 per month among white males. Given a total of male population of 14.1 million in these states, this would indicate an additional 7.78 deaths per month among this demographic group. Note that this figure is almost identical to the one from Panel B, which is not surprising given the smaller and imprecisely estimated 
coefficient for white females as well as the lower homicide rate among white females. Consistent with the results presented in Panel C, the estimates on blacks are small in size and statistically insignificant for both males and females.

The results from the fixed effects Poisson models are presented in Table 4 are largely consistent with those from the OLS. The estimate in column (2) of Panel D indicates that the SYG laws result in an increase in the homicide rate among white males by 9.2 percent, translating into an additional 4.59 homicides per 100,000 residents per month per state among this group. Focusing on the estimates for blacks displayed in Panels $\mathrm{F}$ and $\mathrm{G}$, we see that the estimates are again small in magnitude and imprecisely estimated, indicating that the SYG laws are not causing any effect in homicides among blacks.

The results presented so far refer to the impact of SYG laws that have explicit language extending no duty to retreat to places an individual has a legal right to be. However, some states have passed narrower versions of self-defense laws that limit the no duty to treat only to an individual's home, business, or vehicle, include provisions that create a presumption of reasonableness, or remove civil liability for individuals using deadly force in self-defense. Note that it is the provision of "no duty to retreat in any place an individual has a legal right to be" that is the most controversial aspect of the new SYG laws and it has been this provision that has been at the center of recent debates. In fact, the other provision providing "no duty to retreat at one's home" has been the part of common law for many decades and individuals have rarely been prosecuted for using force, including deadly force, against intruders. Nevertheless, we conducted a robustness analysis to determine the extent to which our results are confounded by these other 
provisions. To do this, we created an additional indicator to reflect whether a state has passed some type of Castle Doctrine law during the analysis period, but one without removing duty to retreat in any place a person has a legal right to be. We call this indicator "Other Self-Defense Provisions." Then we estimate all our models with these two variables. The omitted category in our models is states that did not pass any selfdefense laws during this period.

As shown in Table 5, the OLS results from this analysis barely change from the results reported in Table 3. The estimates on SYG indicator continue to point to a robust impact of SYG laws on homicides among white males. In particular, the estimate of 0.149 for white males translates into about $7.44(0.149 * 0.354 * 14.1$ million/100,000) additional deaths per month. Moreover, the estimates on blacks are still small in size and statistically insignificant. Regarding the coefficients on the indicator for other selfdefense provisions, they are estimated with precision only significant for white males and white females. Surprisingly, however, the estimates are opposite in sign, suggesting that these other provisions are associated with a decrease in the homicide rate among white males while increasing the homicide rate among white females.

The estimates from the fixed effects Poisson results are presented in Table 6. Similarly, these results are statistically indistinguishable from these those shown in Table 4. We interpret this as strong evidence to confirm that the estimated SYG law impacts obtained in our paper are not confounded by these other provisions. For example, the estimate in the second column of Panel A implies that the SYG laws are associated with a 2.6 percent increase in full homicide rate. Focusing on gender and race specific estimates in Panels B through G, we see that the impact of SYG laws on the homicide rate among 
white males is 8.7 percent. Given that the SYG states had an average of 0.354 homicides among white males per 100,000 persons in the month prior to SYG law, the estimate implies that these laws result in about 0.031 additional white males per 100,000 being killed in each state each month. With a white male population of 14.1 million in the SYG states, this is equal to an additional 4.39 deaths among white males per month. Similar to Table 5, all of the SYG estimates on blacks are small in size and none are statistically significant. Regarding the estimates on the indicator for other self-defense provisions, we now obtain negative and statistically significant impacts for white males and black females, while the impact for white females continues to be positive.

In sum, the results presented in Tables 3 through 6 provide no evidence that the SYG laws result in a reduced number of deaths among the citizens in states that have introduced such laws. On the contrary, these results indicate that the number of firearm related homicides among white males increase significantly as a result of these laws.

One potential explanation offered for a positive relationship between SYG laws and homicides is that an increased number of individuals may carry guns in public and willing to use them as a result of these laws (Formby, 2006; Weaver, 2008; Jansen and Nugent-Borakove, 2007). If more individuals, emboldened by the no duty to retreat, are resorting to the use of force in self-defense, then an increased likelihood of gun presence in these situations may result in a rise in homicides. One way to test this is to examine whether gun ownership rises faster in states with a SYG law than other states, employing a difference-in-difference strategy used in our analysis. Unfortunately, data on gun ownership are not available from administrative sources. Therefore, we consider the percentage of suicides involving guns a proxy for gun ownership, which can be 
constructed from the U.S. Vital Statistics data at the state level and monthly frequency. This measure has previously used as a proxy for gun prevalence and shown to be a reliable proxy (Azrael, Cook, and Miller, 2004; Kleck, 2004; Cook, Ludwig, and Samaha, 2009). Using this proxy, we estimated both OLS and Poisson models of the suicide rate on our SYG indicator along with a set of basic controls on the age and racial composition of states. The results from this analysis show that the SYG laws are associated with a statistically significant 2.2 percent increase in gun inflicted suicide rates among white males using the specification in equation (1). However, the estimate loses statistical significance when we include state specific trends. Based on this evidence, we cannot strongly argue that the increased homicides are due to a rise in gun prevalence.

\section{Conclusion}

The controversies surrounding a recent wave of self-defense laws introduced by states have captured the nation's attention recently. Since 2005, a total of 18 states has passed legislation that has extended the no duty to retreat rule to apply to public places and a number of states are debating the adoption of similar legislation. Despite significant implications of these new laws for public safety, there has been little empirical investigation of their impacts. In this paper, we show that SYG laws that extend the right to self-defense to areas outside the home are associated with a significant increase in the number of homicides. Our gender and race specific analyses indicate that the rise in homicides is primarily driven by the deaths among whites, especially white males, while we find no effect on blacks. 
Our results suggest that it is indeed the most controversial aspect of these laws, i.e., the provision that extends no duty to retreat to any place a person has a legal right to be, that causes the increase in homicides. In particular, we show strong evidence to indicate that our results are not driven by other self-defense provisions adopted by states. While our estimates on SYG laws consistently point to a positive impact on homicides, especially among whites, there appears to be no consistency on the impact of other selfdefense provisions. One explanation for this inconsistency may be that the scope of these other self-defense provisions differs greatly among states. For example, some states only created a presumption of reasonableness for those using deadly force in self-defense situations, while others only removed civil liability for those justified under the selfdefense law. Therefore, an analysis that bundles various provisions into one single category may fail to capture the overall impact of these other self-defense provisions properly.

One may argue that the increase in homicides found in our study may be driven by killings that are justified by the SYG laws, i.e., deaths that occur while law-abiding citizens are protecting themselves from intruders or attackers, and that this should not be viewed as a negative outcome. It is possible that some of the additional homicides associated with the SYG law may indeed be driven by the homicides of assailants. However, note that the net increase in homicides cannot be accounted by a one-to-one substitution between killings of assailants and killings of innocent individuals unless multiple assailants are killed in some instances (Cheng and Hoekstra, 2012). If at least some of the additional homicides are due to individuals resorting to the use of deadly force against each other in situations where the threat of death or serious bodily injury is 
not imminent to either party, this could indicate that these laws impose serious costs not only on criminals both also private citizens as well. It is also possible that potential intruders and attackers, who, in the absence of SYG laws, could have gotten away with their crimes without killing or injuring anyone, are now killed as a result of these laws. Whether or not these killings should be considered justified in this case is beyond the purpose of this paper. However, it cannot be argued that the SYG laws are saving the lives of innocent people in this scenario as these individuals would not have been killed in the first place. One of the primary arguments in favor of these laws is that they would have a deterrent effect on crime. However, a net increase in homicides is not consistent with this argument. 


\section{References}

Azrael, D., P.J. Cook, and J. Miller (2004). "State and local prevalence of firearms ownership measurement, structure, and trends." Journal of Quantitative Criminology 20(1): 43-62.

Bedard, K. and H. Frech III (2009). "Prison health care: is contracting out healthy?" Health Economics 18(11): 1248-1260.

Bertrand, M., E. Duflo, and S. Mullainathan (2004). How much should we trust differences-in-differences estimates? Quarterly Journal of Economics, 119:1.

Boots, D. P., J. Bihari, and E. Elliott (2009). "The State of the Castle An Overview of Recent Trends in State Castle Doctrine Legislation and Public Policy." Criminal Justice Review 34(4): 515-535.

Cameron, A. C. and P. K. Trivedi (2005). Microeconometrics: methods and applications, Cambridge University Press.

Catalfamo, C. (2006). "Stand Your Ground: Florida's Castle Doctrine for the Twenty-First Century." Rutgers Journal of Law \& Public Policy 4: 504.

Cheng, C. and M. Hoekstra (2012). "Does Strengthening Self-Defense Law Deter Crime or Escalate Violence? Evidence from Castle Doctrine." NBER Working Paper No. 18134.

Cook, P. and J. Ludwig (2003). "Evaluating Gun Policy. Washington DC, Brookings Institution Press.

Cook, P. and J. Ludwig (2006). "The social costs of gun ownership." Journal of Public Economics, 90(1-2), 379-391.

Cook, P., J. Ludwig, and A. Samaha (2009). "Gun Control after Heller: Litigating against Regulation." National Bureau of Economic Research Working Paper No. 15431, October.

Decker, S. H. and D. C. Pyrooz (2010). "On the Validity and Reliability of Gang Homicide: A Comparison of Disparate Sources." Homicide Studies 14(4): 359-376.

Duggan, M. (2001). "More Guns, More Crime." Journal of Political Economy 109(5).

Federal Bureau of Investigation (2010). Uniform Crime Reports: Crime in the United States.

Florida Stand Your Ground Taskforce (2012). Final Report to Governor's Task Force.

Formby, B. (2006). Bill to seek "castle doctrine" crime protection. Dallas Morning News. 
Harris, A. R., S. H. Thomas, G.A., Fisher, and D.J. Hirsch (2002). "Murder and Medicine: The Lethality of Criminal Assault 1960-1999." Homicide Studies 6(2): 128-166.

Hundley, K., S. T. Martin, et al. (2012). Florida 'Stand Your Ground' Yields Some Shocking Outcomes Depending on How Law is Applied. Tampa Bay Times. Accessed on June 3, 2012 at http://www.tampabay.com/news/publicsafety/crime/article1233133.ece.

Jansen, S. and M. E. Nugent-Borakove (2007). Expansions to the Castle Doctrine: Implications for Policy and Practice, Association of Prosecuting Attorneys.

Kleck, G. (1988). "Crime control through the private use of armed force." Social Problems 35: 1.

Kleck, G. (2004). "Measures of gun ownership levels for macro-level crime and violence research." Journal of Research in Crime and Delinquency 41(1): 3-36.

Kleindienst, L. (2005). Welcome to Florida, But Look Out: Groups Alert Guests to Law, Deadly Force. Sun Sentinel. Accessed on May 20, 2012 at http://articles.sunsentinel.com/2005-09-26/news/0509250378 1_deadly-force-law-seals-prosecutors-andcourts.

Lake, T. (2006). Thanks to New Law, No Case in Shooting. Tampa Bay Times. Accessed on May 20, 2012 at http://www.sptimes.com/2006/07/22/Pasco/Thanks to new_law_no.shtml.

Levin, B. (2011). "A Defensible Defense?: Reexamining Castle Doctrine Statutes." Harvard Journal on Legislation, Vol. 47, No. 2, p. 52.

Loftin, C., D. McDowall, and M.D. Fetzer (2008). "A Comparison of SHR and Vital Statistics Homicide Estimates for US Cities." Journal of Contemporary Criminal Justice 24(1): 4-17.

Lott, J., J.R. and D. B. Mustard (1997). "Crime, deterrence, and right-to-carry concealed handguns." The Journal of Legal Studies 26(1): 1-68.

Lott, J. R. (2001). More guns, less crime: understanding crime and gun-control laws, University of Chicago Press.

MacDonald, J. M. and K. F. Parker (2001). "The Structural Determinants of Justifiable Homicide Assessing the Theoretical and Political Considerations." Homicide Studies 5(3): 187-205.

Megale, E.B. (2010). "Making Murder Legal: How Laws Expanding Self-Defense Allow Criminals to "Get Away with Murder."” Working Paper. Retrieved May 20, 2012 from http://works.bepress.com/elizabeth_megale/1. 
Mocan, H. N. and E. Tekin (2006). "Guns and Juvenile Crime." Journal of Law and Economics 49(2): 507-531.

Montgomery, B. and C. Jenkins (2010). Five Years Since Florida Enacted "Stand-YourGround" Law, Justifiable Homicides are Up. Tampa Bay Times. Accessed on May 15, 2012 at http://www.tampabay.com/news/publicsafety/crime/article1128317.ece.

Mustard, D. B. (2001). "The Impact of Gun Laws on Police Deaths." Journal of Law and Economics 44(S2): 635-657.

NRA-ILA (2006). "Fortifying the Right to Self-Defense." News \& Issues. February 6. Accessed on May 12, 201 at http://nraila.org/news-issues/fact-sheets/2006/fortifying-theright-to-self-defense.aspx. .

Osgood, D. W. (2000). "Poisson-based regression analysis of aggregate crime rates." Journal of Quantitative Criminology 16(1): 21-43.

Palazzolo, J. and R. Barry (2012). More Killings Called Self Defense. Wall Street Journal. New York City.

Project America (2008). Firearms: Ownership: Race. Accessed on May 20, 2012 at http://www.project.org/info.php?recordID=272.

Rios, V. (2012). "Gunfire as Conflict Resolution." The Opinion Pages. The New York Times. March 21.

Rokaw, W. M., J. A. Mercy, et al. (1990). "Comparing death certificate data with FBI crime reporting statistics on US homicides." Public Health Reports 105(5): 447.

Weaver, Z. L. (2008). "Florida's Stand Your Ground Law: The Actual Effects and the Need for Clarification." Miami Law Review, 63(1), 395-430.

Wells, W. and J. Horney (2002). "Weapon Effects And Individual Intent To Do Harm: Influences On The Escalation Of Violence." Criminology 40(2): 265-296.

Wiersema, B., C. Loftin, and D. McDowall (2000). "A comparison of supplementary homicide reports and national vital statistics system homicide estimates for US counties." Homicide Studies 4(4): 317-340. 
Figure 1: Number of States with Stand Your Ground Laws

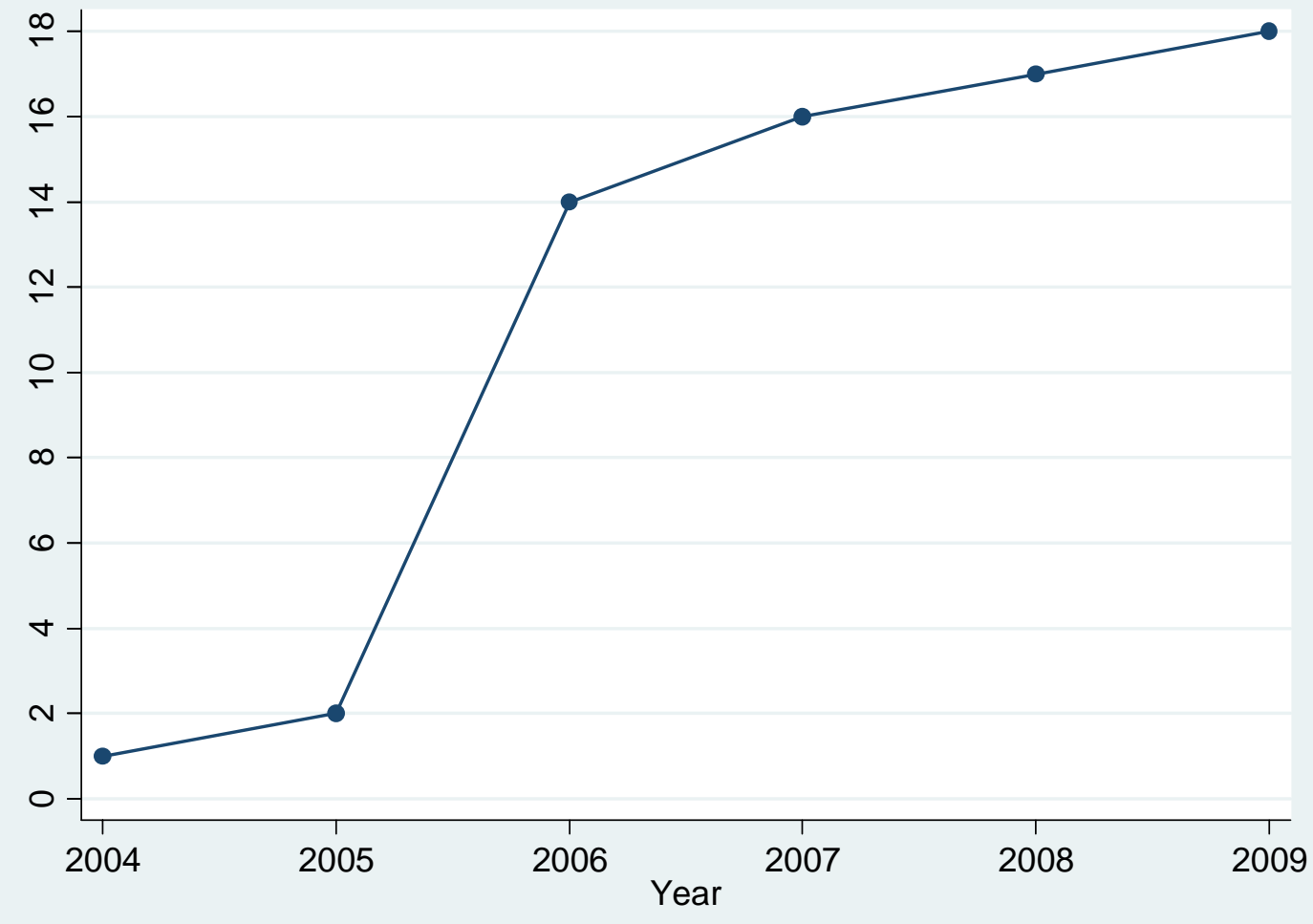


Figure 2: Trends in Homicides Before and After Stand Your Ground Laws Full Sample

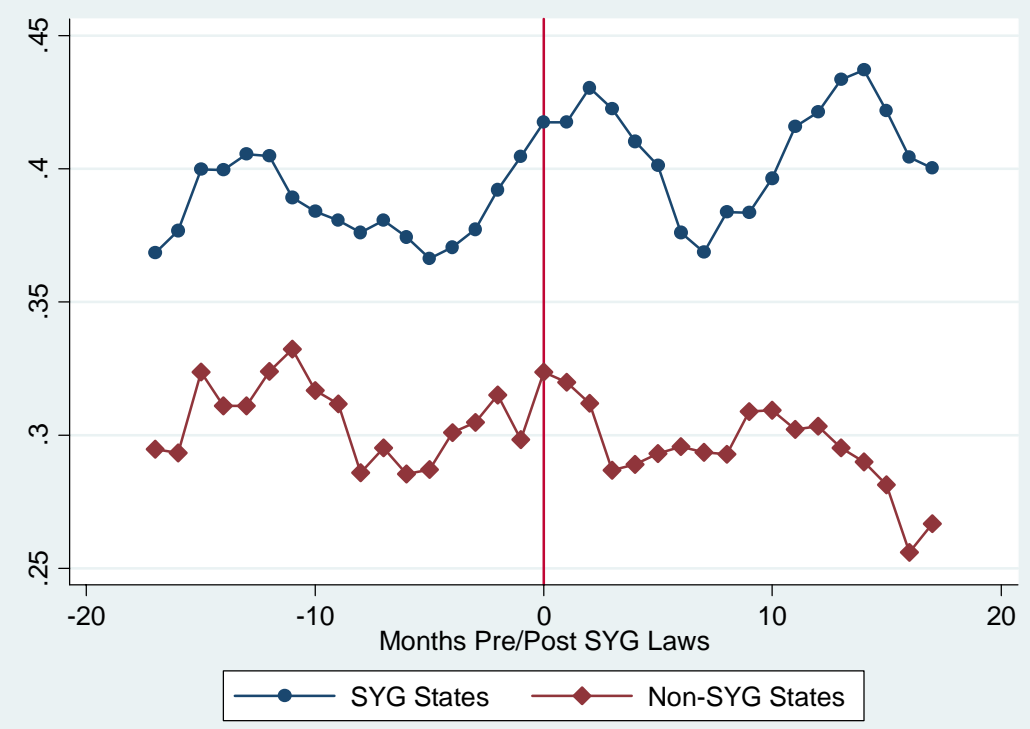

White Males

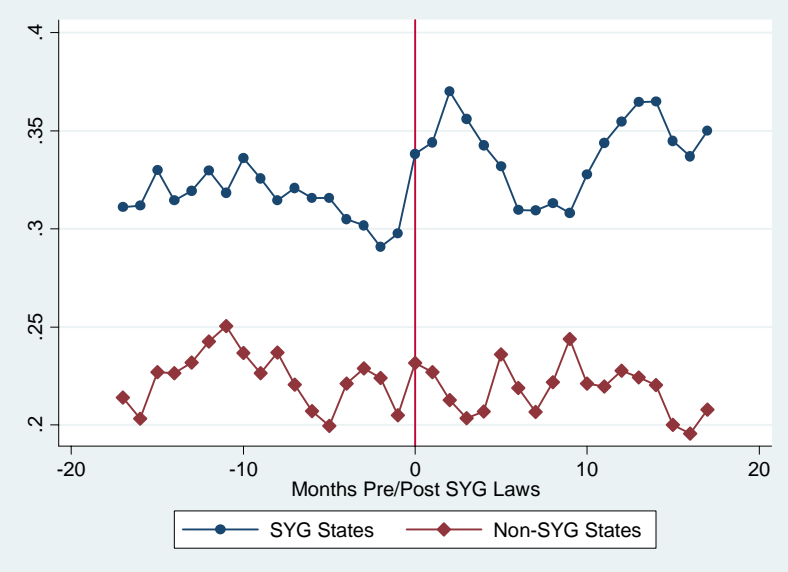

Black Males

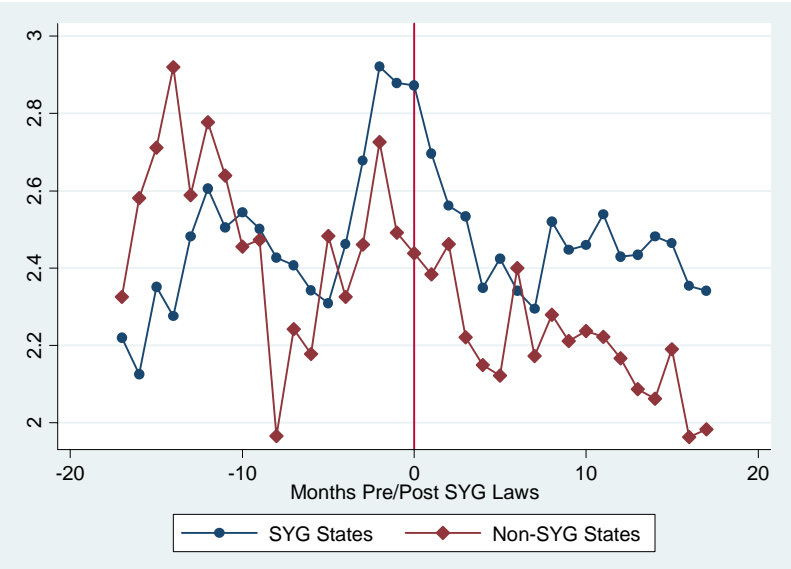

White Females

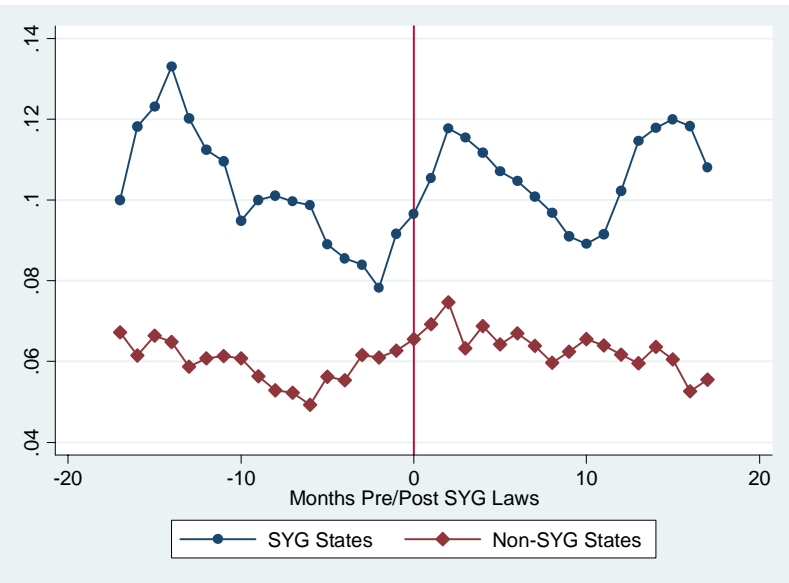

Black Females

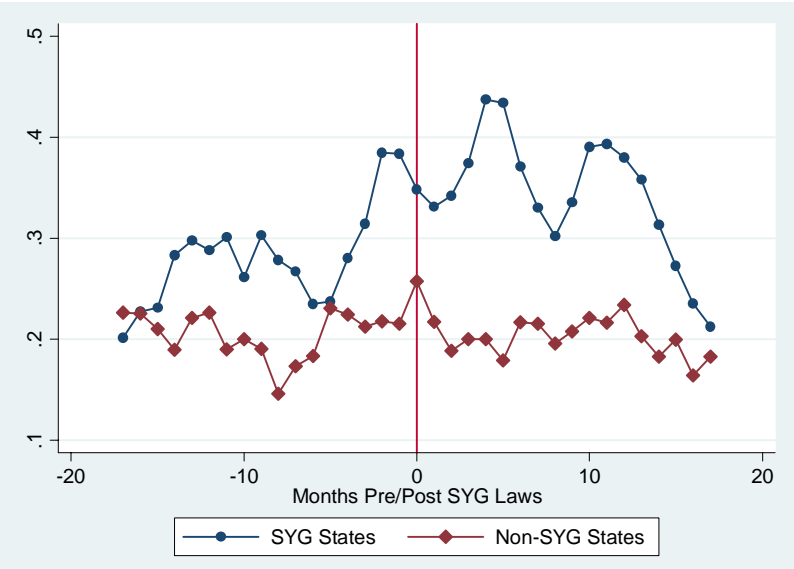


Table 1: States with Stand Your Ground Laws

\begin{tabular}{|c|c|c|c|c|}
\hline - & $\begin{array}{l}\text { No Duty to Retreat in } \\
\text { any place someone has } \\
\text { a legal right to be }\end{array}$ & $\begin{array}{l}\text { Other Castle } \\
\text { Doctrine } \\
\text { Expansion } \\
\end{array}$ & $\begin{array}{l}\text { Effective Date for } \\
\text { SYG }\end{array}$ & Notes/Sources \\
\hline Alabama & 1 & 0 & $6 / 1 / 2006$ & a \\
\hline Alaska & 0 & 1 & $9 / 13 / 2006$ & $\mathrm{~b}$ \\
\hline Arizona & 1 & 0 & $4 / 24 / 2006$ & $\mathrm{~b}$ \\
\hline Arkansas & 0 & 0 & & \\
\hline California & 0 & 0 & & \\
\hline Colorado & 0 & 0 & & \\
\hline Connecticut & 0 & 0 & & \\
\hline Delaware & 0 & 0 & & \\
\hline District of Columbia & 0 & 0 & & \\
\hline Florida & 1 & 0 & $10 / 1 / 2005$ & $\mathrm{a}$ \\
\hline Georgia & 1 & 0 & $7 / 1 / 2006$ & $\mathrm{~b}$ \\
\hline Hawaii & 0 & 0 & & \\
\hline Idaho & 0 & 1 & $7 / 1 / 2006$ & $\mathrm{~b}$ \\
\hline Illinois & 0 & 1 & $7 / 28 / 2004$ & $\mathrm{~b}$ \\
\hline Indiana & 1 & 0 & $7 / 1 / 2006$ & $\mathrm{~b}$ \\
\hline Iowa & 0 & 0 & & \\
\hline Kansas & 1 & 0 & $7 / 1 / 2006$ & $\mathrm{~b}$ \\
\hline Kentucky & 1 & 0 & $7 / 12 / 2006$ & $\mathrm{~b}$ \\
\hline Louisiana & 1 & 0 & $8 / 15 / 2006$ & $\mathrm{c}$ \\
\hline Maine & 0 & 1 & $9 / 20 / 2007$ & $\mathrm{~b}$ \\
\hline Maryland & 0 & 0 & & \\
\hline Massachusetts & 0 & 0 & & \\
\hline Michigan & 1 & 0 & $10 / 1 / 2006$ & $\mathrm{a}$ \\
\hline Minnesota & 0 & 0 & & \\
\hline Mississippi & 1 & 0 & $7 / 1 / 2006$ & $\mathrm{~b}$ \\
\hline Missouri & 0 & 1 & $8 / 28 / 2007$ & $\mathrm{~b}$ \\
\hline Montana & 1 & 0 & $4 / 27 / 2009$ & $\mathrm{a}$ \\
\hline Nebraska & 0 & 0 & & \\
\hline Nevada & 0 & 0 & & \\
\hline New Hampshire & 1 & 0 & $11 / 13 / 2011$ & $\mathrm{~b}$ \\
\hline New Jersey & 0 & 0 & & \\
\hline New Mexico & 0 & 0 & & \\
\hline New York & 0 & 0 & & \\
\hline North Carolina & 0 & 0 & & \\
\hline North Dakota & 0 & 1 & $8 / 1 / 2007$ & $\mathrm{~b}$ \\
\hline Ohio & 0 & 1 & 9/9/2008 & $\mathrm{b}$ \\
\hline Oklahoma & 1 & 0 & $11 / 1 / 2006$ & $\mathrm{a}$ \\
\hline Oregon & 0 & 0 & & \\
\hline Pennsylvania & 0 & 1 & $8 / 28 / 2011$ & $\mathrm{~b}$ \\
\hline Rhode Island & 0 & 0 & & \\
\hline South Carolina & 1 & 0 & $6 / 9 / 2006$ & $\mathrm{~b}$ \\
\hline South Dakota & 1 & 0 & $7 / 1 / 2006$ & $\mathrm{~b}$ \\
\hline Tennessee & 1 & 0 & $5 / 22 / 2007$ & $\mathrm{~b}$ \\
\hline Texas & 1 & 0 & $9 / 1 / 2007$ & $\mathrm{~d}$ \\
\hline Utah & 1 & 0 & $3 / 2 / 1994$ & $\mathrm{~d}$ \\
\hline Vermont & 0 & 0 & & \\
\hline Virginia & 0 & 0 & & \\
\hline
\end{tabular}




\begin{tabular}{lllll} 
Washington & 0 & 0 & & \\
West Virginia & 1 & 0 & $2 / 28 / 2008$ & $\mathrm{~b}$ \\
Wisconsin & 0 & 0 & & $\mathrm{~b}$ \\
Wyoming & 0 & 1 & $7 / 1 / 2008$ & $\mathrm{~b}$ \\
\hline
\end{tabular}

Notes/Sources:

a -NRA-Institute for Legislative Action - http://nraila.org/news-issues/news-from-nra-ila.aspx

b -State Legislators

Alaska - http://www.legis.state.ak.us/basis/get_bill.asp?bill=SB\%20200\&session=24.

Arizona - http://www.supreme.state.az.us/opin/pdf2007/cv060320pr.pdf.

Georgia - http://www1.legis.ga.gov/legis/2005_06/search/sb396.htm.

Idaho - http://legislature.idaho.gov/legislation/2006/S1441.html.

Illinois - http://www.ilga.gov/legislation/publicacts/fulltext.asp?Name=093-0832\&GA=93.

Indiana - http://www.nraila.org/search.aspx?s=\%22Indiana\%22\&sort=date\&pageNum=9.

Kansas - http://www.kslegislature.org/li/b2011_12/measures/sb366/.

Kentucky - http://www.lrc.ky.gov/krs/503-00/085.PDF.

Maine - http://www.mainelegislature.org/legis/bills/bills_123rd/chappdfs/PUBLIC315.pdf.

Michigan - http://www.legislature.mi.gov/documents/2005-2006/publicact/pdf/2006-PA-0311.pdf.

Mississippi - http://billstatus.ls.state.ms.us/documents/2006/html/SB/2400-2499/SB2426PS.htm.

Missouri - http://www.senate.mo.gov/07info/BTS_Web/Bill.aspx?SessionType=R\&BillID=108.

Montana - http://data.opi.mt.gov/bills/2009/billhtml/HB0228.htm.

New Hampshire - http://www.nhliberty.org/bills/view/2011/SB88.

North Dakota- http://www.legis.nd.gov/assembly/60-2007/docs/pdf/2007effectivedatesoflegislation.pdf.

Ohio - http://lsc.state.oh.us/coderev/sen127.nsf/Senate+Bill+Number/0184?OpenDocument.

Oklahoma - http://webserver1.lsb.state.ok.us/2005-06bills/HB/hb2615_engr.rtf.

Pennsylvania - http://www.legis.state.pa.us/WU01/LI/LI/US/HTM/2011/0/0010..HTM.

South Carolina - http://www.schouse.gov/sess116_2005-2006/bills/4301.htm.

South Dakota - http://legis.state.sd.us/sessions/2006/bills/HB1134enr.htm.

Tennessee - http://wapp.capitol.tn.gov/apps/Billinfo/default.aspx?BillNumber=HB1907\&ga=105.

West Virginia-http://www.legis.state.wv.us/Bill_Text_HTML/2008_SESSIONS/RS/Bills/SB145\%20SUB1\%20enr.htm.

Wyoming - http://legisweb.state.wy.us/2008/Summaries/HB0137.htm.

c- Louisiana Association for Justice - http://www.lafj.org/index.cfm?pg=06LegSummaryCriminal.

d- Association for Prosecuting Attorneys (APA) -

http://www.apainc.org/\%28S\%28fcxbywqqevm5y3yplrtrvb45\%29\%29/documentdownload.aspx?documentid=27\&get docnum $=1$. 
Table 2: Summary Statistics

\begin{tabular}{|c|c|c|c|}
\hline Variable & Full Sample & Non-SYG State & SYG State \\
\hline \multirow[t]{2}{*}{ SYG } & 0.123 & 0 & 1 \\
\hline & $(0.329)$ & $(0.000)$ & $(0.000)$ \\
\hline \multirow[t]{2}{*}{ Homicides per month } & 19.514 & 18.806 & 24.551 \\
\hline & $(25.519)$ & $(25.763)$ & $(23.110)$ \\
\hline \multirow[t]{2}{*}{ Monthly Homicide Rate per 100,000} & 0.163 & 0.159 & 0.187 \\
\hline & $(0.179)$ & $(0187)$ & $(0.116)$ \\
\hline \multirow[t]{2}{*}{ \% Hispanic } & 8.556 & 8.536 & 8.699 \\
\hline & $(9.098)$ & $(9.153)$ & $(8.699)$ \\
\hline \multirow[t]{2}{*}{$\%$ White } & 81.763 & 81.808 & 81.444 \\
\hline & $(13.628)$ & $(14.013)$ & $(10.49)$ \\
\hline \multirow[t]{2}{*}{$\%$ Black } & 11.254 & 10.928 & 13.574 \\
\hline & $(11.595)$ & $(11.545)$ & $(11.695)$ \\
\hline \multirow[t]{2}{*}{$\%$ Aged 15-19 } & 7.289 & 7.268 & 7.444 \\
\hline & $(0.563)$ & $(0.524)$ & $(0.773)$ \\
\hline \multirow[t]{2}{*}{$\%$ Aged 20-24 } & 7.13 & 7.041 & 7.764 \\
\hline & $(0.814)$ & $(0.708)$ & $(1.166)$ \\
\hline \multirow[t]{2}{*}{$\%$ Aged 25-34 } & 35.939 & 36.158 & 34.382 \\
\hline & $(1.804)$ & $(1.766)$ & $(1.201)$ \\
\hline \multirow[t]{2}{*}{ \% Living in Urban Areas } & 62.157 & 63.371 & 53.517 \\
\hline & $(30.074)$ & $(28.985)$ & $(35.76)$ \\
\hline \multirow[t]{2}{*}{ Unemployment Rate } & 5.193 & 5.083 & 5.973 \\
\hline & $(1.67)$ & $(1.504)$ & $(2.42)$ \\
\hline \multirow[t]{2}{*}{ Poverty Rate } & 11.998 & 11.718 & 13.991 \\
\hline & $(3.183)$ & $(3.066)$ & $(3.291)$ \\
\hline \multirow[t]{2}{*}{ Democratic Governor } & 0.494 & 0.517 & 0.334 \\
\hline & $(0.5)$ & $(0.5)$ & $(0.472)$ \\
\hline \multirow[t]{2}{*}{ Prisoners per 100,000 Residents } & 431.465 & 420.458 & 509.796 \\
\hline & $(165.03)$ & $(160.876)$ & $(172.948)$ \\
\hline \multirow[t]{2}{*}{ Number of Law Enforcement Agencies } & $19,140.58$ & $19,112.7$ & $19,339.18$ \\
\hline & $(22,325.08)$ & $(22,816.26)$ & $(18,467.53)$ \\
\hline Number of Observations & 6,120 & 5,366 & 754 \\
\hline
\end{tabular}

Note: Standard Deviations are in parentheses. 
Table 3: OLS Estimates of the Impact of the Stand Your Ground Law on Log(Homicides)

\begin{tabular}{|c|c|c|}
\hline \multirow{2}{*}{ A. Full Sample } & \multicolumn{2}{|c|}{ Log(Homicide Rate $)$} \\
\hline & & \\
\hline \multirow[t]{2}{*}{ Stand Your Ground } & $0.096 * *$ & $0.071 * *$ \\
\hline & $(0.036)$ & $(0.035)$ \\
\hline $\mathrm{R}^{2}$ & 0.760 & 0.773 \\
\hline \multicolumn{3}{|l|}{ B. Whites } \\
\hline \multirow[t]{2}{*}{ Stand Your Ground } & $0.108 * *$ & $0.122 * *$ \\
\hline & $(0.046)$ & $(0.056)$ \\
\hline $\mathrm{R}^{2}$ & 0.674 & 0.683 \\
\hline \multicolumn{3}{|l|}{ C. Blacks } \\
\hline \multirow[t]{2}{*}{ Stand Your Ground } & 0.056 & -0.053 \\
\hline & $(0.065)$ & $(0.098)$ \\
\hline $\mathrm{R}^{2}$ & 0.623 & 0.644 \\
\hline \multicolumn{3}{|l|}{ D. White Males } \\
\hline \multirow[t]{2}{*}{ Stand Your Ground } & $0.123 * *$ & $0.156 * *$ \\
\hline & $(0.046)$ & $(0.058)$ \\
\hline $\mathrm{R}^{2}$ & 0.673 & 0.682 \\
\hline \multicolumn{3}{|l|}{ E. White Females } \\
\hline \multirow[t]{2}{*}{ Stand Your Ground } & 0.077 & 0.073 \\
\hline & $(0.048)$ & $(0.083)$ \\
\hline $\mathrm{R}^{2}$ & 0.520 & 0.525 \\
\hline \multicolumn{3}{|l|}{ F. Black Males } \\
\hline \multirow[t]{2}{*}{ Stand Your Ground } & 0.074 & -0.048 \\
\hline & $(0.065)$ & $(0.098)$ \\
\hline $\mathrm{R}^{2}$ & 0.622 & 0.642 \\
\hline \multicolumn{3}{|l|}{ G. Black Females } \\
\hline \multirow[t]{2}{*}{ Stand Your Ground } & -0.007 & -0.041 \\
\hline & $(0.067)$ & $(0.096)$ \\
\hline $\mathrm{R}^{2}$ & 0.564 & 0.570 \\
\hline Time-Varying State Characteristics & Yes & Yes \\
\hline State Fixed Effects & Yes & Yes \\
\hline Month*Year Fixed Effects & Yes & Yes \\
\hline State-Specific Linear Time Trends & No & Yes \\
\hline Number of Observations & 6,120 & 6,120 \\
\hline
\end{tabular}

Notes: Each cell presents the coefficient on the indicator for Stand Your Ground Law. Standard errors are clustered by state are in parentheses. The unit of observation is state-month-year. All regressions are weighted by state population of the relevant demographic group. *, **, and *** indicate that the Stand Your Ground coefficient is statistically significant at the $0.10,0.05$ and 0.01 levels, respectively. 
Table 4: Fixed Effects Poisson Estimates of the Impact of the Stand Your Ground Law on Homicides

\begin{tabular}{|c|c|c|}
\hline & & \\
\hline A. Full Sample & & \\
\hline Stand Your Ground & $0.031 * *$ & $0.025^{*}$ \\
\hline & $(0.016)$ & $(0.013)$ \\
\hline Pseudo- $\mathrm{R}^{2}$ & 0.211 & 0.212 \\
\hline B. Whites & & \\
\hline Stand Your Ground & $0.057 * *$ & $0.051^{*}$ \\
\hline & $(0.025)$ & $(0.031)$ \\
\hline Pseudo- $\mathrm{R}^{2}$ & 0.187 & 0.189 \\
\hline C. Blacks & & \\
\hline Stand Your Ground & 0.012 & -0.000 \\
\hline & $(0.023)$ & $(0.024)$ \\
\hline Pseudo-R ${ }^{2}$ & 0.206 & 0.208 \\
\hline D. White Males & & \\
\hline Stand Your Ground & $0.078 * * *$ & $0.092 * * *$ \\
\hline & $(0.029)$ & $(0.033)$ \\
\hline Pseudo-R ${ }^{2}$ & 0.198 & 0.200 \\
\hline E. White Females & & \\
\hline Stand Your Ground & 0.035 & 0.062 \\
\hline & $(0.052)$ & $(0.071)$ \\
\hline Pseudo-R ${ }^{2}$ & 0.160 & 0.164 \\
\hline F. Black Males & & \\
\hline Stand Your Ground & 0.022 & 0.010 \\
\hline & $(0.024)$ & $(0.026)$ \\
\hline Pseudo-R ${ }^{2}$ & 0.207 & 0.209 \\
\hline G. Black Females & & \\
\hline Stand Your Ground & -0.002 & 0.075 \\
\hline & $(0.079)$ & $(0.108)$ \\
\hline Pseudo- $\mathrm{R}^{2}$ & 0.116 & 0.120 \\
\hline Time-Varying State Characteristics & Yes & Yes \\
\hline State Fixed Effects & Yes & Yes \\
\hline Month*Year Fixed Effects & Yes & Yes \\
\hline State-Specific Linear Time Trends & No & Yes \\
\hline Number of Observations & 6,120 & 6,120 \\
\hline
\end{tabular}

Notes: Each cell presents the coefficient on the indicator for Stand Your Ground Law. Standard errors are clustered by state are in parentheses. Outcome variable is the natural $\log$ of the number of homicides. The unit of observation is state-month-year. All models include the logarithm of state population for the relevant demographic group as an additional control variable. ${ }^{*}, * *$, and *** indicate that the Stand Your Ground coefficient is statistically significant at the $0.10,0.05$ and 0.01 levels, respectively. 
Table 5: OLS Estimates of the Impact of the Stand Your Ground and Other Self-Defense Laws on Homicides

\begin{tabular}{|c|c|c|}
\hline & & \\
\hline A. Full Sample & & \\
\hline Stand Your Ground & $0.093 * *$ & $0.068^{*}$ \\
\hline & $(0.037)$ & $(0.035)$ \\
\hline Other Self-Defense Provisions & -0.026 & -0.053 \\
\hline & $(0.093)$ & $(0.085)$ \\
\hline $\mathrm{R}^{2}$ & 0.760 & 0.773 \\
\hline B. White & & \\
\hline Stand Your Ground & $0.100^{* *}$ & $0.120^{* *}$ \\
\hline & $(0.047)$ & $(0.058)$ \\
\hline Any Self-Defense Law & -0.066 & -0.036 \\
\hline & $(0.107)$ & $(0.061)$ \\
\hline $\mathrm{R}^{2}$ & 0.674 & 0.683 \\
\hline C. Blacks & & \\
\hline Stand Your Ground & 0.050 & -0.058 \\
\hline & $(0.069)$ & $(0.098)$ \\
\hline Other Self-Defense Provisions & -0.045 & -0.124 \\
\hline & $(0.092)$ & $(0.113)$ \\
\hline $\mathrm{R}^{2}$ & 0.623 & 0.645 \\
\hline D. White Males & & \\
\hline Stand Your Ground & $0.109 * *$ & $0.149^{* *}$ \\
\hline & $(0.049)$ & $(0.060)$ \\
\hline Other Self-Defense Provisions & -0.115 & $-0.122 * * *$ \\
\hline & $(0.091)$ & $(0.038)$ \\
\hline $\mathrm{R}^{2}$ & 0.674 & 0.682 \\
\hline E. White Females & & \\
\hline Stand Your Ground & $0.090 * *$ & 0.086 \\
\hline & $(0.044)$ & $(0.079)$ \\
\hline Other Self-Defense Provisions & 0.103 & 0.233 \\
\hline & $(0.121)$ & $(0.141)$ \\
\hline $\mathrm{R}^{2}$ & 0.520 & 0.526 \\
\hline F. Black Males & & \\
\hline Stand Your Ground & 0.066 & -0.054 \\
\hline & $(0.069)$ & $(0.098)$ \\
\hline Other Self-Defense Provisions & -0.059 & -0.140 \\
\hline & $(0.095)$ & $(0.112)$ \\
\hline $\mathrm{R}^{2}$ & 0.622 & 0.642 \\
\hline G. Black Females & & \\
\hline Stand Your Ground & 0.002 & -0.045 \\
\hline & $(0.069)$ & $(0.097)$ \\
\hline Other Self-Defense Provisions & 0.069 & -0.087 \\
\hline & $(0.048)$ & $(0.086)$ \\
\hline $\mathrm{R}^{2}$ & 0.564 & 0.57 \\
\hline Time-Varying State Characteristics & Yes & Yes \\
\hline State Fixed Effects & Yes & Yes \\
\hline Month*Year Fixed Effects & Yes & Yes \\
\hline State-Specific Linear Time Trends & No & Yes \\
\hline
\end{tabular}

Notes: Standard errors are clustered by state are in parentheses. *, **, and *** indicate that the Stand Your Ground coefficient is statistically significant at the $0.10,0.05$ and 0.01 levels, respectively. 
Table 6: Fixed Effects Poisson of the Impact of the Stand Your Ground and Any SelfDefense Laws on Homicides

\begin{tabular}{|c|c|c|}
\hline \multirow{2}{*}{ A. Full Sample } & \multicolumn{2}{|c|}{ Log(Homicide $)$} \\
\hline & & \\
\hline Stand Your Ground & $0.032 * *$ & $0.026^{* *}$ \\
\hline \multirow{2}{*}{ Other Self-Defense Provisions } & $\begin{array}{c}(0.016) \\
0.003\end{array}$ & $\begin{array}{c}(0.013) \\
0.012\end{array}$ \\
\hline & $(0.037)$ & $(0.037)$ \\
\hline Pseudo- $\mathrm{R}^{2}$ & 0.211 & 0.212 \\
\hline \multicolumn{3}{|l|}{ B. White } \\
\hline \multirow[t]{2}{*}{ Stand Your Ground } & $0.055^{* *}$ & 0.050 \\
\hline & $(0.025)$ & $(0.031)$ \\
\hline \multirow[t]{2}{*}{ Any Self-Defense Law } & -0.012 & -0.016 \\
\hline & $(0.054)$ & $(0.034)$ \\
\hline Pseudo- $\mathrm{R}^{2}$ & 0.187 & 0.189 \\
\hline \multicolumn{3}{|l|}{ C. Blacks } \\
\hline \multirow[t]{2}{*}{ Stand Your Ground } & 0.010 & -0.001 \\
\hline & $(0.025)$ & $(0.023)$ \\
\hline \multirow[t]{2}{*}{ Other Self-Defense Provisions } & -0.014 & -0.006 \\
\hline & $(0.043)$ & $(0.056)$ \\
\hline Pseudo-R ${ }^{2}$ & 0.206 & 0.208 \\
\hline \multicolumn{3}{|l|}{ D. White Males } \\
\hline \multirow[t]{2}{*}{ Stand Your Ground } & $0.072 * *$ & $0.087 * * *$ \\
\hline & $(0.030)$ & $(0.033)$ \\
\hline \multirow{2}{*}{ Other Self-Defense Provisions } & -0.056 & $-0.108 * * *$ \\
\hline & $(0.043)$ & $(0.035)$ \\
\hline Pseudo- $\mathrm{R}^{2}$ & 0.198 & 0.200 \\
\hline \multicolumn{3}{|l|}{ E. White Females } \\
\hline \multirow[t]{2}{*}{ Stand Your Ground } & 0.056 & 0.079 \\
\hline & $(0.048)$ & $(0.067)$ \\
\hline \multirow[t]{2}{*}{ Other Self-Defense Provisions } & 0.177 & $0.370^{* *}$ \\
\hline & $(0.179)$ & $(0.168)$ \\
\hline Pseudo-R ${ }^{2}$ & 0.160 & 0.164 \\
\hline \multicolumn{3}{|l|}{ F. Black Males } \\
\hline \multirow[t]{2}{*}{ Stand Your Ground } & 0.019 & 0.009 \\
\hline & $(0.025)$ & $(0.025)$ \\
\hline \multirow[t]{2}{*}{ Other Self-Defense Provisions } & -0.019 & -0.010 \\
\hline & $(0.044)$ & $(0.056)$ \\
\hline Pseudo-R ${ }^{2}$ & 0.207 & 0.209 \\
\hline \multicolumn{3}{|l|}{ G. Black Females } \\
\hline \multirow[t]{2}{*}{ Stand Your Ground } & 0.011 & 0.072 \\
\hline & $(0.080)$ & $(0.109)$ \\
\hline \multirow[t]{2}{*}{ Other Self-Defense Provisions } & 0.084 & $-0.097 *$ \\
\hline & $(0.062)$ & $(0.053)$ \\
\hline Pseudo-R ${ }^{2}$ & 0.116 & 0.120 \\
\hline Time-Varying State Characteristics & Yes & Yes \\
\hline State Fixed Effects & Yes & Yes \\
\hline Month*Year Fixed Effects & Yes & Yes \\
\hline State-Specific Linear Time Trends & No & Yes \\
\hline
\end{tabular}

Notes: Standard errors are clustered by state are in parentheses. ${ }^{*}, * *$, and $* * *$ indicate that the Stand Your Ground coefficient is statistically significant at the $0.10,0.05$ and 0.01 levels, respectively 


\section{Appendix Table 1: OLS Estimates of the Impact of the Stand Your Ground Law on}

Homicides

\begin{tabular}{|c|c|c|}
\hline & Homicid & idents \\
\hline A. Full Sample & & \\
\hline Stand Your Ground & $0.033 * *$ & $0.026^{*}$ \\
\hline & $(0.013)$ & $(0.015)$ \\
\hline $\mathrm{R}^{2}$ & 0.778 & 0.794 \\
\hline B. Whites & & \\
\hline Stand Your Ground & $0.025 * *$ & $0.033 * *$ \\
\hline & $(0.010)$ & $(0.013)$ \\
\hline $\mathrm{R}^{2}$ & 0.683 & 0.696 \\
\hline C. Blacks & & \\
\hline Stand Your Ground & 0.077 & -0.000 \\
\hline & $(0.070)$ & $(0.090)$ \\
\hline $\mathrm{R}^{2}$ & 0.591 & 0.609 \\
\hline D. White Males & & \\
\hline Stand Your Ground & $0.043 * *$ & $0.055 * * *$ \\
\hline & $(0.016)$ & $(0.020)$ \\
\hline $\mathrm{R}^{2}$ & 0.694 & 0.707 \\
\hline E. White Females & & \\
\hline Stand Your Ground & 0.008 & 0.011 \\
\hline & $(0.005)$ & $(0.008)$ \\
\hline $\mathrm{R}^{2}$ & 0.257 & 0.265 \\
\hline F. Black Males & & \\
\hline Stand Your Ground & 0.188 & 0.009 \\
\hline & $(0.129)$ & $(0.169)$ \\
\hline $\mathrm{R}^{2}$ & 0.600 & 0.617 \\
\hline G. Black Females & & \\
\hline Stand Your Ground & -0.021 & -0.008 \\
\hline & $(0.019)$ & $(0.025)$ \\
\hline $\mathrm{R}^{2}$ & 0.146 & 0.155 \\
\hline Time-Varying State Characteristics & Yes & Yes \\
\hline State Fixed Effects & Yes & Yes \\
\hline Month*Year Fixed Effects & Yes & Yes \\
\hline State-Specific Linear Time Trends & No & Yes \\
\hline Number of Observations & 6,120 & 6,120 \\
\hline
\end{tabular}

Notes: Each cell presents the coefficient on the indicator for Stand Your Ground Law. Standard errors are clustered by state are in parentheses. The unit of observation is state-month-year. All regressions are weighted by state population of the relevant demographic group. *, **, and *** indicate that the Stand Your Ground coefficient is statistically significant at the $0.10,0.05$ and 0.01 levels, respectively. 